indicator crops will be the subject of later publications.

This work was carried out with the aid of a special grant from the Agricultural Research Council, to which grateful acknowledgment is made.

Delphine A. Hoyxe

G. E. G. Mattingly

Department of Horticulture,

University, Reading.

$$
\text { July } 31 \text {. }
$$

Waksman, S. A., and Tenney, F. G., Soil Sci., 24, 317 (1927) ; 26, 155 (1928). Norman, A. G., Ann. App. Biol., 20, 146 (1933) Sci., 16, 90 (1946).

Rubins, E. J., and Bear, F. E., Soil Sci., 54, 411 (1942). Bould, C., and Winsor, G. W., J. Sci. Food Agric., 2, 125 (1951).

\section{Physiological Effects of the Volatile Products of Respiring Potatoes}

Ix has long been known that the dormancy of potatoes may be prolonged by volatile substances evolved by ripe apples ${ }^{1}$. The active substance may be ethylene, which is evolved by ripe apples ${ }^{2}$ and which retards the sprouting of potatoes ${ }^{3}$. Ethylene is also found in the volatile products of bananas", avocados ${ }^{5}$, pears ${ }^{6}$, and various citrus fruits ${ }^{7}$. In view of these observations, it now appears that the physiological effects eaused by the accumulation of respira. tory products are not necessarily due to the presence of carbon dioxide, though this assumption has been made ${ }^{8,8}$. The prolongation of the dormancy of potatoes is one of the effects which have been attributed to the accumulation of respiratory carbon dioxide ${ }^{10}$.

During recent work it has been shown that if the volatile metabolic products of potatoes were allowed to accumulate, the sprouting of potatoes was retarded. If, however, the carbon dioxide alone was allowed to accumulate, but the other volatile products were removed by circulating the atmosphere through 96 per cent sulphuric acid containing 2 per cent w/v silver sulphate, sprouting was stimulated. This effect could possibly have been due to oxygen depletion, though this is improbable. Sprouting was markedly retarded by scrubbing out all the carbon dioxide in the storage atmosphere but allowing the other volatile metabolic products to accumulate. These results are illustrated in the accompanying table. Further work has indicated that two groups of growth-inhibiting volatile substances are evolved by stored potatoes. The members of one group are absorbed in 96 per cent sulphuric acid, which does not, however, absorb the members of the second group. The latter, which may be absorbed in 96 per cent sulphuric acid activated by silver sulphate, are

EFFECT OF STORAGE ATMOSPHERE UPON THE SPROdTING OF MAJESTTC POTATOES STORED FOR 15 WEEKS AT $10^{\circ} \mathrm{C}$.

\begin{tabular}{|c|c|c|c|c|}
\hline \multicolumn{2}{|c|}{ Storage atmosphere* } & \multirow{2}{*}{$\begin{array}{l}\text { Volatiles } \\
\text { other than } \\
\text { carbon } \\
\text { dioxide }\end{array}$} & \multirow{2}{*}{$\begin{array}{l}\text { Wt. of } \\
\text { sprouts as } \\
\% \text { of that of } \\
\text { sprouted } \\
\text { tubers }\end{array}$} & \multirow{2}{*}{$\begin{array}{l}\text { Length of } \\
\text { storage in } \\
\text { exp. atmo- } \\
\text { sphere } \\
\text { (days) }\end{array}$} \\
\hline $\begin{array}{l}\text { Carbon } \\
\text { dioxide } \\
(\%)\end{array}$ & $\begin{array}{c}\text { Oxygen } \\
(\%)\end{array}$ & & & \\
\hline $\begin{array}{c}5 \cdot 6-7 \cdot 3 \\
0 \cdot 03 \\
4 \cdot 8-7 \cdot 1 \\
0 \cdot 0\end{array}$ & $\begin{array}{c}12 \cdot 9-14 \cdot 5 \\
20 \cdot 8 \\
12 \cdot 9-15 \cdot 0 \\
16 \cdot 8-19 \cdot 8\end{array}$ & $\begin{array}{l}\text { Absent } \\
\text { Absent } \\
\text { Present } \\
\text { Present }\end{array}$ & $\begin{array}{l}3 \cdot 4 \\
1.2 \\
0 \cdot 8 \\
0 \cdot 0\end{array}$ & $\begin{array}{l}76 \\
95 \\
76 \\
95\end{array}$ \\
\hline
\end{tabular}

* Analysis of air entering the potato containers. In every case the atmosphere was circulated through the containers (holding $31.7-$ $31.8 \mathrm{kgm}$, potatoes) and the absorbing system at a rate of about 2) litres an hour. The oxygen was replenished as used. probably olefines and, by analogy with fruit ${ }^{2}$, this group may consist almost entirely of ethylene.

The work described in this communication was carried out as part of the programme of the Food Investigation Organization of the Department of Scientific and Industrial Research.

$$
\text { W. G. Burton }
$$

Ditton Laboratory,

(Department of Scientific and Industrial Research), East Malling, Kent.

$$
\text { Oct. } 2 \text {. }
$$

${ }^{1}$ Elmer, O. H., Science, 75, 191 (1932).

${ }^{2}$ Gane, R., Nature, 134, 1008 (1934).

${ }^{3}$ Huelin, F. E., Rep. Food Invest. Board for 1932, 51 (1933).

- Niederl, J. B., Brenner, M. W., and Kelley, J. N., Amer. J. Bot. 25, $357^{\circ}(1938)$.

${ }^{3}$ Pratt, H. K., Young, R. E., and Biale, J. B., Plant Physiol., 23, 526 (1948).

- Gane, R., Rep. Food Invest. Board for 1938, 142 (1939).

'Miller, E. V., Winston, J. R., and Fisher, D. F., J. Agric. Res. 60, $269(1940)$

${ }^{8}$ Kidd, F., Proc. Roy. Soc., B, 87, 408 (1914).

- Mer, C. L., and Richards, F. J., Nature, 165, 179 (1950).

${ }^{10}$ Kardos, L. T., and Blood, P. T., Amer. Potato J., 24, 39 (1947).

\section{Bacteriophage Inactivation by Antiphage Serum Diluted in Distilled Water}

THE fraction $f$ of bacteriophages remaining active $t$ minutes after having been mixed with antiphage serum may be expressed by the following relation ${ }^{1}$ :

$$
f=\exp (-k t / D),
$$

in which $D$ represents the dilution of the serum. The rate constant $k$, therefore, is a measure of the potency of the serum. Usually, $k$ is determined by diluting the serum and the suspension of virus particles in nutrient broth or buffered saline, in which media a good serum may, at $37^{\circ} \mathrm{C}$., show a $k$-value of 500-1,000 per min. Hence, in order to reduce the fraction of surviving virus particles, $f$, to less than 1 per cent within an hour, such a serum cannot be diluted by more than $10^{4}$.

I have found that nutrient broth and buffered saline must contain factors which inhibit the inactivation of bacteriophages by antiphage serum, as the rate of inactivation can be greatly increased by making the reaction take place in distilled water. Moreover, the interaction of phage with antiphage appears to require the presence of a third factor, since very high dilutions of antiphage serum in distilled water will not cause observable virus inactiva. tion, unless small amounts of normal serum, or of peptone, are added.

Thus, rabbit antiphage serum (showing a $k$-value of 600 , in broth), diluted by a factor of $10^{8}$ in distilled water, can be mixed with a suspension of bacteriophages in distilled water, without the occurrence of observable inactivation. Rapid inectivation, corresponding to a $k$-value of 100,000 or more, will follow when normal serum at a concentration of 20-1,000 gamma per ml., or peptone at a concentration of $50-2,000$ gamma per ml., is added to such a mixture. Higher concentrations of these substances have been found to inhibit the process of inactivation. Concentrations of monovalent ions exceeding about $10^{-2}$ molar, and of calcium ions exceeding about $10^{-3}$ molar, were also found to be inhibitive. The general shape of the inactivation curves, when making the reaction proceed in distilled water, is the same 